UDC 579:579.64:631.86/87

(C) 2016

V. Volkogon, Corresponding Member of the National Academy of Sciences of Ukraine, Doctor of Agricultural Sciences

S. Dimova, M. Miahka, Candidates of Agricultural Sciences

S. Derkach, N. Lutsenko, N. Shtanko

Institute of Agricultural Microbiology and Agro-Industrial Production of NAAS

L. Tsentilo, Candidate of Agricultural Sciences

LLC Agrofirma Kolos

\title{
BIOENRICHMENT OF POULTRY MANURE BY ASSOCIATION OF A FUNGUS TRICHODERMA HARZIANUM
}

The purpose. To study features of growth of association of fungi Trichoderma harzianum 128 at enrichment of compost of organic matter on the basis of poultry manure and to evaluate perspectives of bioenrichment of compost. Methods.

Laboratory (for simulation of process of bioenrichment); industrial (approbation of technique of enrichment); field (determination of efficiency of compost at growing potato); statistical. Results. In conditions of model experiments the optimum terms of introduction in compost substrate of agronomically valuable microorganisms depending on their predominant functions are fixed. Application of T. harzianum 128 for 2-nd month of enrichment of compost promotes prompt growth of strange micromycets. Efficiency of technique is shown under production conditions. The gained biocompost is characterized by heightened total carbon and nitrogen, positively influences productivity of potato and product quality. Conclusions. Enrichment of compost of substrate on the basis of poultry manure at add-on of association of T. harzianum 128 ensures intensification of mineralization processes and accumulation of agronomically valuable microorganisms - active destructors of organic matter and producers of physiologically active joints. The gained biocompost is perspective for use in farming industry.

Key words: compost, successions of assemblages of microorganisms, poultry manure, Trichoderma harzianum.

Characteristic features of modern and promising apple varieties are fecundity, the ability to enter ferns on the second - the third year after planting in the garden, to quickly increase yields from year to year [1]. Research results F.H. Alston and I.W. Bates [2], T.Visser [3] and R.S. Shidakova [4] showed that the above-mentioned properties are positively correlated with the yield, which in the apple varieties is genetically determined and depends on the number of generative kidneys and the ability to tie fruits that are stored despite abnormal natural 
phenomena, namely: the fall of the hail, strong wind, sharp fluctuations in temperature (drought, heat and cold), mushroom disease, pests and the like.

Many scientists believe that the early and intense fruiting sources are Alkmen, Antor, Askold, Idared, Golden Resistient, Golden Delishes, Carol, Mantet, Jonathan, Grennie Smith, Winter Lemon, Renet Simirenko, Horneygold, Radogost, Rosavka, Teremok [5, 6, 7, 8, 9]. According to P.V. Kondratenka [10], T.E. Kondratenko [11], O.V. Melnyk [12], the most rapidly growing and yielding in the zone of the forest-steppe of Ukraine, are most marked by Antey, Askold, Gala, Cimeria, Kulikovsky, Quinti, Mantet, Teremok, Radogost, Rovessnik, Rumy Mountaineer.

The productive value of a variety that can be offered for introduction into production as a means of improving the productivity of the main fruit crop determines its breeding and yield.

The purpose of our research was to comprehensively study new varieties of apple of foreign selection and allocation of perspective, whose plants are adapted to the conditions of the western forest-steppe Ukraine. One of the main tasks was to determine the degree of their fecundity and yield.

Methods and conditions. The laying of experiments, all records and observations were carried out in accordance with the "Program and method of sorting fruit, berry and nut tree crops" [13].

The objects of research are 10 foreign and three control varieties - Idared, Calvay Snow and Renet Simire DP "Novosilky" of the Institute of Horticulture (IS) of NAASU in spring 2002 under the scheme of $4 \times 3 \mathrm{~m}$, crown shape - spindle bush in the absence of irrigation.

The soil of the experimental site is dark gray, podzolized, medium-sandy, on a carbonate forest, typical for the forest-steppe zone.

The climate of the region is moderately continental. Rainfall reaches $597 \mathrm{~mm}$. The smallest period of research $(521 \mathrm{~mm}$ ) was recorded in 2007, the largest (728) - in 2005. The long-term amount of active temperatures of $100 \mathrm{C}$ and above is $25800 \mathrm{C}$, the average annual temperature of air is $5,80 \mathrm{C}$. The sum of active temperatures ( 10 ${ }^{\circ} \mathrm{C}$ and above) ranged from 2882 (2006) to $3244^{\circ} \mathrm{C}$ (2010). Most of the winters were "soft", the minimum air temperature was minus $17.2-22.00 \mathrm{C}$, the more severe (2006) - minus 28.50 C. Weather conditions of growing periods 2004-2007, 2010 and 2011. were unstable, but generally satisfactory for normal growth and development of trees.

Research results. Early fertility of a variety is determined by the term of its introduction into fruiting and the rate of growth of yield. Sometimes the introduction of apple into fruiting is considered to be the year when at least $50 \%$ of the registered tree species are formed by $3 \mathrm{~kg}$ of fruit and more [14]. 
Estimation of the terms of the introduction of the studied varieties in fruiting showed that in the third year of growth yields at the level of control or significantly higher was in Antea plants - $3.1 \mathrm{~kg} /$ dec. (2.6 t / ha), Vessalini - $3.0 \mathrm{~kg} /$ well. (2.5 t / ha), Zaslavsky - $8.0 \mathrm{~kg} /$ dec. (6.7 t / ha), Nadzeini - $6.8 \mathrm{~kg} /$ well. (5.7 t / ha) and Syagrin - $4.3 \mathrm{~kg} /$ well. (3.6 t / ha). In the following year (2005), for the most part (85\%) varieties, this indicator was only $1.0-2.1 \mathrm{~kg} / \mathrm{dec}$. Single fruits were recorded on the trees of Zaslavsky and Remembrance Syabarova (Table 1). The yield of the Imanta was $5.1 \mathrm{~kg} /$ der. The reason for the weak laying of flower buds in the above-mentioned varieties is due, apparently, to a small amount of precipitation in June and the first decade of July 2004 of the previous year (3.4 and $14.2 \mathrm{~mm}$ ) - respectively. During this period, the plants of Antey and Nadzeyne were characterized by stable yields without its growth (Table 1 ). The introduction into fruiting for the fifth year (2006) of growth was noted in the trees of the varieties Alysya, Vernbnoe, Kalvyly snow (k.), P'amyati Syubarova and Chavrnitsa; Their yield was $3.3-11.7 \mathrm{~kg} /$ dec. At the latest, they began to bear the fruits of Renet Simirenko, whose yield for the sixth year of growth amounted to $5.1 \mathrm{t} /$ ha (Table 2).

Table 1

Characteristics of flowering and yield of apple trees during the period of introduction into fruiting, 2004 - 2005 IS NAAN, State Enterprise "Novosilki"

\begin{tabular}{|c|c|c|c|c|c|}
\hline \multirow[t]{2}{*}{ Varyant } & $\begin{array}{l}\text { The } \\
\text { degree of } \\
\text { flowering, } \\
\text { ball }\end{array}$ & kg / year & $\begin{array}{l}\text { The degree } \\
\text { of } \\
\text { flowering, } \\
\text { ball }\end{array}$ & Yield, kg / yr. & \multirow[t]{2}{*}{$\begin{array}{l}\text { Year } \\
\text { introduction } \\
\text { into fruit- } \\
\text { wearing }\end{array}$} \\
\hline & \multicolumn{2}{|l|}{2004} & \multicolumn{2}{|l|}{2005} & \\
\hline Idared (k.) & 4,0 & 3,6 & 2,5 & 2,1 & Third \\
\hline Alessia & 3,0 & 1,1 & 2,5 & 0,4 & Fifth \\
\hline Antey & 3,8 & 3,1 & 1,0 & 3,2 & Third \\
\hline Vrbnoye & 0,1 & $\begin{array}{l}\text { Single } \\
\text { fruits }\end{array}$ & 4,5 & 1,1 & Fifth \\
\hline Vsesilina & 8,0 & 3,0 & 1,0 & 1,3 & Third \\
\hline Zaslavsky & 5,0 & 8,0 & 1,0 & Single fruits & Third \\
\hline Imant & 6,0 & 1,9 & 3,0 & 5,1 & Fourth \\
\hline $\begin{array}{l}\text { Calvi } \text { Snow } \\
\text { (k.) }\end{array}$ & 3,0 & 2,3 & 7,0 & 1,2 & Fifth \\
\hline Nadjeyny & 4,3 & 6,8 & 2,0 & 4,1 & Third \\
\hline Memory of & Single & 0,1 & 4,5 & Single fruits & Fifth \\
\hline
\end{tabular}




\begin{tabular}{|l|l|l|l|l|l|}
\hline Syubarova & $\begin{array}{l}\text { infloresce } \\
\text { nces }\end{array}$ & & & & \\
\hline $\begin{array}{l}\text { Renet } \\
\text { Simirenko } \\
(\mathrm{k} .)\end{array}$ & 5,0 & 2,5 & 5,0 & 1,0 & Sixth \\
\hline Syabrin & 5,5 & 4,3 & 7,0 & 2,1 & Third \\
\hline Chavranice & Single & 0,1 & 4,0 & 1,1 & Fifth \\
\hline SSD $_{05}$ & & 0,83 & & 0,51 & \\
\hline
\end{tabular}

Trees of the studied varieties entered fruiting in the seventh (2008) year of growth. The highest yields in this period (15.0 - $21.9 \mathrm{t} / \mathrm{ha}$ ) were recorded in Antey, Vernbnoe, Nadzeyni, Syabariny and Chavrantsi, low in Aydarid (12.5 t / ha), Zaslavsky (13.3), Imanta (13.6), in the memory of Syubarova (12.3), even lower (7.8-9.3 t / ha) in Alesi, Vsesaliny and the controlling Snow Calvy and Renet Simirenko (Table 2). In general, the fruiting of most of the varieties in that year was very weak, the yield was $0.25-8.30$ tons per hectare. The following year (2009), the intensity of flowering of most varieties was 2.0-3.0, and in Idared, Imanta, Memory of Suebarova and Syberni - 5 - 7 points. The reason was the adverse weather conditions. So, although humidity in July of the previous year (2008) and was sufficient (87.4 mm), 86.5\% of precipitation occurred in the first decade of the month, when the maximum air temperature (+36 0C) was noted. Thus, insufficient soil moisture in the third decade of July in combination with air drought and high air temperature negatively affected the laying of flower buds of most of the studied varieties. In 2009, when their trees were in the "pink bud" phase, frostbite was observed (in the third decade of April to minus $3.50{ }^{\circ} \mathrm{C}$ ). All this influenced the formation of their harvest. In the same year (2009), the high percentage of fruit fastening was recorded in the varieties Alysya, Vernbinoe, Vsesilina, and despite the weak flowering (2-3 points), their yield was 5.5-8.3 $\mathrm{t}$ / ha.

At the age of nine (2010), this indicator was high (over $25 \mathrm{t} / \mathrm{ha}$ ) in control varieties (Calville Snow and Renet Simirenko) and in Antea (Table 2). At the level with them foster-bearing trees were Zaslavsky, Nadzeiny, Pamyaty Syabarovoy and Sybery. The latter trees formed the highest yield for the whole period of study - $50.6 \mathrm{t} /$ ha. The yields of Idared, Alyus, Vrbnoye and Imant were also counted (19.9 - $24.0 \mathrm{t} / \mathrm{ha}$ ), and the least yielding ones were Vsesylina (14.5 t / ha) and Chavarnitsu (18.3). In 2011, the Kalwil snow (control), and also Vernbinoe and Vsesilina, which yielded 19.3-24.0 t / ha, were stable in 2011. In the trees of Alesi and the Memorial of Syabarov, this figure was 13.4 and $13.7 \mathrm{t} /$ ha respectively. In 
all other varieties, the yield was very low (1.8 - $5.3 \mathrm{t} / \mathrm{ha})$, while Zaslavsky and Renet Simirenko trees did not bear fruit at all.

Table 2

Yields of the studied Belarusian apple varieties (2002: garden, $4 \times 3 \mathrm{~m}$, rootstock 54-118), 2006-2012, state enterprise "Novosilki"

\begin{tabular}{|l|l|l|l|l|l|l|l|c|}
\hline \multirow{2}{*}{} & \multicolumn{7}{|c|}{ Yield (t / ha) over the years } \\
\cline { 2 - 10 } & 2006 & 2007 & 2008 & 2009 & 2010 & 2011 & 2012 & $\begin{array}{c}\text { average for } \\
2009 \text { - 2012 }\end{array}$ \\
\hline Idared (k.) & 7,5 & 5,0 & 12,5 & 3,3 & 23,1 & 5,0 & 23,3 & 13,7 \\
\hline Alessia & 7,0 & 2,7 & 9,4 & 5,5 & 24,0 & 13,0 & 21,3 & 15,9 \\
\hline Antey & 16,1 & 0,1 & 21,7 & 0,4 & 41,0 & 1,8 & 30,0 & 18,3 \\
\hline Vrbnoye & 6,6 & 3,0 & 21,3 & 6,2 & 20,1 & 19,3 & 14,5 & 15,0 \\
\hline Vsesilina & 4,6 & 3,0 & 9,3 & 8,3 & 14,5 & 22,5 & 7,5 & 13,2 \\
\hline Zaslavsky & 15,1 & 0,16 & 13,3 & 1,6 & 39,6 & 0,0 & 30,8 & 18,0 \\
\hline Imant & 1,1 & 7,6 & 13,6 & 4,0 & 19,9 & 5,3 & 10,8 & 10,0 \\
\hline $\begin{array}{l}\text { Calvi Snow } \\
\text { (k.) }\end{array}$ & 2,8 & 3,3 & 8,1 & 1,4 & 27,8 & 24,0 & 21,6 & 16,9 \\
\hline Nadjeyny & 16,3 & 2,0 & 18,3 & 3,0 & 28,6 & 2,6 & 27,4 & 15,4 \\
\hline $\begin{array}{l}\text { Memory of } \\
\text { Syubarova }\end{array}$ & 6,7 & 5,5 & 12,3 & 4,0 & 28,1 & 13,4 & 17,5 & 15,8 \\
\hline $\begin{array}{l}\text { Renet } \\
\text { Simirenko } \\
\text { (k.) }\end{array}$ & 0,6 & 5,1 & 7,8 & 0,25 & 38,5 & 0,0 & 29,0 & 18,7 \\
\hline Syabrin & 16,4 & 7,3 & 16,6 & 8,0 & 50,6 & 2,2 & 33,3 & 23,5 \\
\hline Chavranice & 9,8 & 0,3 & 15,0 & 0,5 & 18,3 & 13,7 & 22,2 & 13,7 \\
\hline SSD 05 & 4,30 & 3,53 & 3,71 & 2,55 & 10,44 & 5,17 & 8,46 & 6,10 \\
\hline
\end{tabular}

The following year (2012) high yields (29.0 $\mathrm{t} / \mathrm{ha}$ ) formed the plants of the Renet Simirenko variety (k.), With Antey, Zaslavsky, Syabarin and Nadjeyny (Table 2). Yields (21.3 - $23.3 \mathrm{t} / \mathrm{ha})$ were also trees of the varieties Aidared (k), Alysya, Kalvyly snow (k.) And Chavrnitsa. 
The results of calculating the coefficient of periodicity of fruit bearing in the six nine - year plantation showed that most of the studied Belarusian varieties are characterized by irregular fruiting. Varieties of Antey, Graf Ezzo, Zaslavsky, Nadzeiny and Renet Simirenko are characterized by periodic fecundity (J more than 75\%). Annually, the trees of the control grade Calville snowy fruited ( $\mathrm{J}=$ $39 \%)$.

Conclusions Studies have shown that the Antey, Nadzeyna, and Syabarine varieties in growing on a subsoil of 54-118 rainfed conditions (Western Foreststeppe) are characterized by a high rate of fast-growing trees and annual fruiting in the first years after planting in the garden. Early introduction to fruiting was noted at the trees of Aydared (k.), Vsesilini and Zaslavsky.

In the age of full fruiting on the rich, the harvest was recognized as Siabrin (23.53 t / ha), medium-yielding Antey, Zaslavsky, Nadzeyne, Alysya, Vernbnoe and Memorial Syubarova.

\section{Bibliography}

1. Gaponenko B.K. Your garden/B.K. Gaponenko, MB Gaponenko - K.: Harvest, 1994. - 400 p.

2. Alston F.H. Selection for yield in apple progenies/F.H. Alston, I.W. Bates//Proc. Tree Fruit. Symp - 1979. - P. 15-27.

3. Visser T. Environmental and genetic factors influencing the juvenile period in apple/T. Visser//Proc. Fruit Symp - 1970 - pp. 101-115.

4. Shidakov R.S. The apple tree variety and its improvement through breeding in the foothills of the North Caucasus/R.S. Shidakov - Nalchik, 1991. - 302 pp.

5. Dovbish O.P. Some results of apple cultivar study in Podillya Ukraine/O.P. Dovbish//Horticulture. - 1998. - № 46. - P. 37-38.

6. Kanashina R.O. Implication of fecundity by hybrid offspring/R.O. Kanashina//Modern problems and prospects of gardening development: abstracts of reports to the 25th anniversary of Podilsky station. - Vinnytsya, 1994. - P. 2526.

7. Kichina V.V. Productivity and Its Biological Limits in Modern Concepts of the Science of a Class in Horticulture/VV Kicchia//The problem of productivity of fruit and berry cultures: Dokl. scientific - productions. Sovetsch (Moscow, Zagorje, September 9-12, 1996). - M., 1996. - P. 79 - 86.

8. Kopan V.P. Methods and sources of selection of apple tree breeding, productivity, compact habit of growth and fruiting/VP Kopan, KN Copan//Selection of an apple of intensive type: session method. commissions otd. 
Plant Production and Selection VASKHNIL (abstracts of reports). - K., 1983. - P. 24-27.

9. Sedov E.N. Commodity and consumer qualities of fruits/E.N. Sedov, N.G.Krasov, Z.A.Sedov//Catalog of apple varieties (Variety Fund and its use). Eagle: Eagle otd Trick book Izd-va, 1981. - P. 91-103.

10. Kondratenko P.V. Ways of accelerating the introduction of apple plantations in fruiting/P.V. Kondratenko//Horticulture. - 1997. - № 45. - P. 27-32.

11. Kondratenko T.E. An update of the industrial assortment of apples in Ukraine/T.E. Kondratenko//Mater. international scientific - practice conf. "Agriculture of the 21st Century - Problems and Solutions". - K.: Nora-Print, 1999. - P. 191-192.

12. Melnyk O.V. Gala - the sort of future/O.V. Melnik//Gardening News. - 2011. №1. - P. 35

13. Program and method of sorting fruit, berry and nut tree crops [ed. E.N. Sedova, T.P. Ogoltsovaya] - Eagle: A publication of the All-Russian Research Institute of Fruit Selection Selection, 1999. - 608 p. 